\title{
Democracy on the lam: Crisis, constitutionalism and extra-legality
}

\author{
Jennet Kirkpatrick \\ Department of Political Science, University of Michigan, Ann Arbor, Michigan 48109, USA. \\ jennetk@umich.edu
}

\begin{abstract}
Sheldon S. Wolin's theory of fugitive democracy has been both lauded and criticized for its radical departure from the mainstays of democratic theory: formal institutions, political offices and constitutional arrangements of power. For Wolin, democracy is correctly understood as an ephemeral event that appears unexpectedly when ordinary citizens, united by a shared grievance, collectively interrupt normal political proceedings and reject constitutionalism. This article critically analyzes Wolin's theory in light of a historical phenomenon in which citizens collectively interrupted politics: frontier vigilantism in the American West from 1850 to 1900 . Critical of Wolin's wholesale rejection of constitutionalism, the article reveals the potentially legalistic patterns of extra-legal collective action, and it argues for de-fetishizing democratic practice that occurs outside of institutional channels.
\end{abstract}

Contemporary Political Theory (2012) 11, 264-284. doi:10.1057/cpt.2011.28; published online 20 September 2011

Keywords: democracy; constitutionalism; pluralism; exception

In the spring of 1856 in San Francisco, several thousand citizens stormed the county jail and, aiming a cannon at Sheriff David Scannell, kidnapped two men being held for murder. Eventually known as the San Francisco Vigilance Committee of 1856, an appellation intended to signify the democratic legitimacy of a civic association that swelled to some 6000 members, this group was founded on antipathy toward the formal workings of law. Although by 1856 San Francisco was a vibrant metropolis of 50000 replete with police, a courthouse, judges, juries, lawyers and federal marshals, vigilantes believed that the legal had become illegal and formal justice abetted injustice. Answering the question 'who shall rule, the decent respectable, honest citizens; or the rowdies, gamblers and murderers?', vigilantes chose the former, seeing themselves as the best representatives of what was right, proper and aboveboard. As they saw it, their capacity to act was secured by the principle of popular sovereignty, an ideal which meant that the right to enforce the law 'reverts back to the people

(C) 2012 Macmillan Publishers Ltd. 1470-8914 Contemporary Political Theory Vol. 11, 3, 264-284 www.palgrave-journals.com/cpt/ 
from whom it was wrested' in a time of crisis (Smith, 1883, p. 46). Thus, they recreated the law to their liking, forming an ad hoc popular tribunal to try the two men and, after finding them guilty, killing them. Both were hanged from the second-story windows of the vigilante headquarters.

How can this intriguing episode and others like it enrich democratic theory? What should democratic theorists make of events in which citizens, responding to an emergency, take the law into their own hands? From one perspective, the answer is very small. If democracy is equated with the establishment of legitimate constitutional forms, then events that occur outside of these forms are of little assistance in describing its virtues, proclivities or risks. If we see democracy 'like the state', to borrow a felicitous phrase from James Scott, then unruly episodes will matter little to democratic theory.

Sheldon S. Wolin offers a divergent perspective, arguing that democracy in the late modern period is properly understood as 'fugitive'. For Wolin, democracy appears not as a kind of regime or as an institutional political form, but rather as an exceptional, finite moment in which ordinary people, acting together in the name of a common concern, transgress against and interrupt the constitutional boundaries fixed by the state. As Wolin sees it, democracy is antithetical to constitutionalism, the establishment of settled practices that define authority, jurisdiction, accountability and the way of life of the polity. In contrast, fugitive democracy is evanescent and episodic.

Because Wolin's democratic theory inverts the accepted binaries and constructs the marginal as central, it brings events like those of San Francisco in 1856 into the scope of democratic theorizing and it creates an opportunity to revise democratic theory in light of these events. I take up this project here using the phenomenon of frontier vigilantism to examine and ultimately criticize Wolin's theory of fugitive democracy and to better understand extralegal democratic practices. The phenomenon of frontier vigilantism, which occurred in the American West from approximately 1850 to 1900, is an illuminating and appropriate case for analysis because of the noteworthy connections with the theory of fugitive democracy. Wolin himself identifies 'the westward migrations where new settlements and towns were founded by the hundreds' on the American frontier as an example of the 'restorative power of democracy' (Wolin, 1996, p. 43). Although the individual cases vary in some respects, frontier vigilantism generally involved groups of citizens interrupting established constitutional forms, wresting the executive power to punish from the state, and disbanding once their work was done. Given these connections, I explore this historical, empirical phenomenon in order to expose an unanticipated concern it raises for Wolin's theory and to gain insight into collective action in the extra-legal realm.

Analyzing Wolin's theory in light of the phenomenon of frontier vigilantism reveals a crucial area of concern, namely its treatment of constitutionalism 
and democracy as binary and antithetical terms. Examining a historical case suggests that the relationship between democracy and constitutionalism is more complex and nuanced than the theory allows. It is true that frontier vigilantes pointedly rejected the formal legal and constitutional restraints placed on them, minimal as they were, and that their collective actions were fashioned as a negation of existing constitutional arrangements. However, this is only half of their history. Many frontier vigilantes also constituted a temporary legal form that both fit their immediate needs and gave structure and meaning to their actions. This legal form did not spring sui generis. It was rooted, instead, in the very constitutional structures that frontier vigilantes disparaged. In other words, these frontier vigilantes did not reject constitutionalism wholly. Their actions are best characterized by the binaries that they straddle, rather than by an unqualified rejection of one element in favor of the other. Many frontier vigilantes acted in the space between negation and creation, formlessness and forms, chaos and order, will and law, and novelty and tradition. In addition to pointing to a problem in Wolin's theory, the tendency of frontier vigilantes to lean heavily on an existing legal form provides insight into extra-legal democratic practice. As frontier vigilantes found, stepping into the extra-legal realm is a consequential political undertaking that demands a rare political capacity to found and to lead.

Reading a theory of fugitive democracy with an empirical case of extra-legal collective action in mind is significant because it resists fetishizing democracy or endowing it with an unerring power of goodness. To moralize spontaneous collective democratic action, to make it stand for all good things, is to focus on the allure of the extra-legal realm at the expense of its terror (and terror, thus ignored, becomes all the more terrifying). This analysis of fugitive democracy also connects it more firmly to the burgeoning literature on 'states of exception', those moments when the sovereign transcends or interrupts the rule of law in the name of the public good (Scheuerman, 1994, pp. 123-156; McCormick, 1997, pp. 121, 156; Kalyvas, 2008). Following Schmitt's famous statement in Political Theology, 'The sovereign is he who decides on the exception', examinations of the exception have tended to focus on 'he' - that is, on the state official, usually the executive, who is seen as the embodiment of sovereignty (Schmitt, 2005, p. 5). Phenomena like frontier vigilantism suggest pluralizing Schmitt's pronoun: 'they' can act as well as a 'he' (Frank, 2007, pp. 103-120; Honig, 2007, pp. 78-102; 2009, pp. xv-xviii). This history pushes exploration of states of exception by political actors who are quite distinct from the executive - that is, a mixed, motley group that is separate from the state and unencumbered by elected or appointed political office. Although the 'they' examined here is from the long-gone past, I hope this article will encourage debate about contemporary democratic theory and about popular struggles for democracy unfolding at present and in the future. In order to more fully analyze uprisings like the 'Arab Spring' and to appreciate them as

266 (C) 2012 Macmillan Publishers Ltd. 1470-8914 Contemporary Political Theory Vol. 11, 3, 264-284 
wondrous, strenuous and perilous political events, we need a lively exchange about the role of constitutions and law within popular movements acting in the name of democracy.

Toward the goal of better understanding extra-legal collective action, the first section of the article explores Wolin's theoretical argument, drawing attention to the central characteristics that define and mark it as distinct. Although far from an exhaustive treatment, this first section provides a brief and focused overview of Wolin's position and focuses on the issue of violence within his theory. The next section turns to frontier vigilantism, narrowing in on elements of the phenomenon that are relevant to the theory. Two areas stand out: their fascination with a unified, homogeneous sovereign people and their unexpected approach to constitutionalism. The final section uses the empirical data from frontier vigilantism to criticize Wolin's argument. This section argues for maintaining an uncomfortable and awkward tension between democracy and constitutionalism, especially in moments of spontaneous collective action.

\section{Fugitive Democracy: Taking Back Power}

While the original article entitled 'Fugitive Democracy' was published in 1994, the theory exceeds the neat and tidy boundaries of any single, solitary piece of writing; it has been quilted over time. Crucial components of fugitive democracy appear as early as 1960 in Wolin's criticism of the organizational impulses of Saint-Simon and of modern constitutionalism. The theory makes a reappearance in the final chapter of Wolin's (2004) revision of Politics and Vision, the final section of which bears the title 'Fugitive Democracy', and also in Wolin's (2008) Democracy Incorporated. Although this gradual process of development has yielded a theory that is both rich and evocative, it has also blunted the theory's sharper edges (Kateb, 2001, p. 44; Ball, 2002, p. 943). At the periphery, much remains unspecified and open to interpretation. At the core, however, there is far less enigma. Fugitive democracy has several distinct characteristics that distinguish it from conventional theories of democracy and that give insight into why it has generated both excitement and unease among democratic theorists.

Foremost, fugitive democracy represents a bred-in-the-bones rejection of constitutionalism, the dominant approach to politics in late modernity. For Wolin, contemporary constitutions have an expansive reach; their embrace is more sweeping than identifying primary and secondary rules of obligation, as H.L.A. Hart had it and their influence is more extensive than serving as a precommitment device against the dangerous tendencies of democratic majorities, as Jon Elster puts it (Hart, 1961; Elster, 2000). Wolin's concept of constitutions in late modernity is closer to Aristotle's: constitutions identify a regime 
and a way of life (Aristotle, 1984, IV, pp. 11, 1295a40-b1). Thus, for Wolin, constitutions today not only mark the boundaries of legality and illegality, but they also regulate 'the amount of politics, the temporal rhythms or periodicity of politics, and they give it ritualistic forms' (Wolin, 1996, p. 34). In particular, constitutions delimit when the demos can express itself and how it can express itself by channeling its voice through voting booths and jury deliberating rooms. As Wolin sees it, constitutions also superintend economic life because they establish the preconditions for economic exploitation and serve the interests of the nation-state and the economic elite (Wolin, 1994, p. 35). Contemporary constitutions even touch the internal realm. By encouraging the internalization of universal rules, constitutions condition subjectivity; they increase mediocrity and annul the extremes of human desire. Along with the wicked desires like deception and foolishness so goes the desire for excellence (Wolin, 2004, pp. 403-405).

Between constitutions and democracy there is scarce common ground (Honig, 2001, p. 799; Brown, 2007, p. 14). Constitutions domesticate democracy and ossify politics, rendering both regularized and rationalized. Constitutions and democracy are 'two diametrically opposed notions that symbolize two equally opposed states of affairs' (Wolin, 1994, p. 29). Rather than aiming at wholesale suppression or annihilation, late-modern constitutions furrow democracy for its own purposes. This antagonism means that constitutional democracy, properly understood, is a misnomer. Constitutional democracy 'is not democratic' quite simply '... because it is a democracy without the demos as an actor' (Wolin, 1996, p. 34). For Wolin, the modifier 'constitutional' alters the meaning of the noun entirely. 'Constitutional democracy' does not signify a type of democracy, but rather a managerial approach to democracy that muzzles it into normalized and normalizing forms. Although he describes their dominance in vigorous terms, Wolin is careful to point out that the mastery of constitutions is not inevitable or transhistorical. Rather, it is rooted in the rise of 'advanced industrial democracies' and the triumph of early American figures like Madison and Hamilton, who were able to construct effective constitutional barriers to democratic power.

For Wolin, the rise of constitutionalism in late modernity has given way to another modern historical development, fugitive democracy. In this fleeting kind of political action, Wolin argues, the constitution ceases to function as a political, economic or internal restraint, and the locus of power, agency and action shifts to 'the community' or 'the people' (Wolin, 1996, p. 41). For an ephemeral moment, a portion of the people simultaneously recalls the unruly, inclusive, centrifugal character of democracy and chafes against the exclusionary, centripetal forces of constitutionalism. The forgotten demos, that is, the ordinary and the poor, come out from the shadows of formal politics and, experiencing an unpremeditated sense of commonality, they remember their

268 (C) 2012 Macmillan Publishers Ltd. 1470-8914 Contemporary Political Theory Vol. 11, 3, 264-284 
political power and act collectively to reclaim it. Examples of fugitive democracy are of two sorts. First, there are those that are rooted in the exercise of political founding, such as the American founding, the failed attempt to refound America on the basis of racial equality, and the founding of frontier communities in the American West. The second type consists of popular political movements, such as the Abolitionist movement, the women's suffrage movement, the labor movement, the civil rights movement and the ecology movement (Wolin, 1996, p. 43). These examples of fugitive democracy are united for Wolin by their tendency to momentarily disrupt class and status systems that limit political participation to the elite and by their ability to instill commonality and solidarity among the demos. A purer, more originary expression of the demos, fugitive democracy is impermanent, polymorphous, episodic and tends to transgress inherited forms.

Wolin takes particular care to describe the political actor at the heart of fugitive democracy, the 'people' or the 'community', as an 'evanescent homogeneity' (Wolin, 1996, p. 44). Although the prescriptive meaning of this intriguing phrase is not explained in detail, its negative meaning is more fully developed: the people resists making a virtue of leveling, homogeneity or any kind of oneness that suppresses what is novel, idiosyncratic or singular. Wolin concedes that some sense of commonality is essential for democratic politics the demos must be a 'we' in some sense to act - and thus he sets out to theorize commonality without a hatred of the imperfect, the novel or the solitary (Wolin, 1993, p. 472; 1996, pp. 43-44).

Evanescent homogeneity can by be accomplished, Wolin suggests, by removing the intentional goal of homogeneity and by embracing a kind of commonality that arises naturally or spontaneously. Like fugitive democracy itself, homogeneity should bubble up from below in an unforced way, arising out of a confluence of events or interests. This kind of homogeneity is 'a perfect coincidence of (or between) interests' (Wolin, 1996, p. 44). Rather than an assault on heterogeneity, evanescent homogeneity is a 'norm' that forms without premeditation or external stimulus and is devoid of aspirational goals of oneness. In addition to citing Polish Solidarity as an example, Wolin rereads the Lockean state of nature as a 'metaphor of lost commonality' that reveals the possibility of escaping the logic of purification (Wolin, 1996, p. 41). As Wolin sees it, the state of nature is a condition of homogeneity that permits the 'suspension of heterogeneity' (not its annihilation) because individuals make an obligation to observe the law of nature and to treat others as free and equal beings (Wolin, 1996, p. 41). This imaginary form of evanescent homogeneity is created through a voluntary act of agreement that is endogenously motivated and that resists the lure of oneness, completion or purity. It arises from below, not from above, and is confirmed through an action by the collective itself, not a dictate from an official or a decree from the state. ${ }^{1}$ 
The dominant metaphor for Wolin in describing fugitive democracy is of going back or taking back. Fugitive democracy is a 'restorative moment' of 'democratic renewal'. It is 'remembered', 'recreated', 'retrieve[d]' and 'recall[ed]'. Underlying this regenerative moment is the active repossession of power: As Wolin puts it, 'the taking back of one's powers is the crucial move' (Wolin, 1994, p. 57; 1996, pp. 41-44).

This raises the question: What kind of powers do the people take back? Are these returned powers peaceful or violent? For Wolin, the power that the state wields is certainly violent, and thus it seems logical to ask whether the power repossessed by the people is violent as well. It seems plausible, moreover, that the state might not want to return powers to the demos. If so, how will the people take them back? Throughout much of his work, Wolin has emphasized that the collective public actions that constitute the 'political' should be oriented toward speech, not violence. As he puts it, 'a free society' can 'enjoy moments of commonality when, through public deliberations, collective power is used to promote or protect the well-being of the collectivity' (Wolin, 1996, p. 31). Wolin's emphasis on speech is also apparent in his involvement with and writings about the Berkeley Free Speech Movement in the 1960s, a series of protests in which Mario Savio famously removed his shoes to address crowds from atop a police car.

Given this, it is surprising that Wolin does not disavow violence in 'Fugitive Democracy', and may even permit it. With little fanfare or warning, Wolin states that fugitive '[d]emocracy is a rebellious moment that may assume revolutionary, destructive proportions, or may not' (Wolin, 1996, p. 43). This remarkable statement certainly allows for a kind of fugitive democracy that is oriented solely toward speech and deliberation, a position that given Wolin's long-standing focus on speech makes sense. But it also imagines and implicitly sanctions a violent, destructive sort of collective action. Although his theory is not focused on violence or destruction, Wolin gestures toward the possibility of both elsewhere. He writes, for instance, that it is by stasis, not physis, that the demos acquires a civic nature' (Wolin, 1996, p. 38). Stasis is a term that readers of Thucydides will readily associate with his description of the bloody and brutal Corcyrean stasis, or civil strife, in book three of his History of the Peloponnesian War. If we follow Thucydides - an author Wolin references repeatedly - stasis not only means domestic discord, but violent unrest. Wolin also runs up against the issue of collective violence in his analysis of 'antimodern centrifugals' like 'the Klan, militiamen and -women, neo-Nazis ... and champions of an "original Constitution", Wolin does not censure these groups for using brute force, but instead he directs attention to the political work that they do. Anti-modern centrifugals are 'provocateurs whose passionate commitments can arouse self-consciousness in the public', and they prompt 'controversies' which are crucial to the 'cause of anti-totality and its vitality' (Wolin, 2004, p. 604).

270 (C) 2012 Macmillan Publishers Ltd. 1470-8914 Contemporary Political Theory Vol. 11, 3, 264-284 
Wolin also opens up the question of violence with his argument that fugitive democracy is conceptually allied with revolution. Fugitive democracy is 'rooted in revolution', 'identified with revolution' and 'revolutionary transgression is the means by which the demos makes itself political' (Wolin, 1994, pp. 30, 37; 1996, p. 38). As Wolin sees it, the relationship between democracy and revolution is long-standing: 'historically modern democracy and ancient Athenian democracy all emerged in combination with revolution' (Wolin, 1996, p. 37). Some of the revolutions Wolin cites are known for their violence, whereas others are known for an absence of violence. Here again, Wolin focuses on what fugitive democracy accomplishes - the appearance of an enlarged and active demos - while leaving the question of how it is to be accomplished open. It may well be that Wolin intends the actors themselves to decide. Decisions about means occur on the street, not in the armchair.

If so, this remarkable deference to the actors on the ground reveals Wolin to be a thoroughgoing democrat who is centrally concerned with securing the demos as the political actor and less concerned with the unfortunate decisions or potential chaos that might result. It also gives the theory an open-ended and unscripted quality that is unsettling and discomforting. Seeing fugitive democracy as steeped in negation, critics have suggested that it represents an overreaching rejection of the political inheritances of modernity and that it verges on a nihilistic form of destruction rooted in rage, resentment, envy and rancor. It negates, rejects, opposes too much (Kateb, 2001, p. 40; Beiner, 2004, p. 62). A second line of criticism draws attention to the insufficiencies of the theory to maintain 'evanescent homogeneity' and to foster pluralism within moments of fugitive democracy (Connolly, 2001, p. 17; Xenos, 2001, p. 33). The problem, these critics contend, is not that Wolin's theory advocates nihilism, destruction or an antipathy toward plurality. The problem, instead, is that the theory's ecumenical approach toward collective action inhibits addressing the possibility of nihilism, destruction and antipathy. As one sympathetic critic puts it, it 'is difficult, at least for someone like me, not to find Wolin's radical democratic conception of the political inspiring. And yet, the more I ponder its trajectory and ethos, the more I find it to be tailored to what is too extraordinary, too heroic' (White, 2001, p. 177). For those with concerns about naturalizing the heroism of collective actors involved in exceptional political events, Wolin offers little solace. Fugitive democracy may assume 'revolutionary, destructive proportions or may not'.

\section{Go West, Fugitive Democracy!}

Part of the appeal of a theory of fugitive democracy is that it cunningly inverts the conventional critiques of democracy long associated with Plato, Aristotle 
and Bodin, among others. Democracy, so the argument goes, is unruly, chaotic and potentially violent; it heedlessly violates established order and accepted rules; it shuns expertise and disregards hierarchies; impelled by the logic of equality, it tends toward formlessness. Wolin affirms these observations, noting, 'democracy is wayward, inchoate, unable to rule yet unwilling to be ruled. It does not naturally conform. It is inherently formless' (Wolin, 1994, p. 50). At the same time, Wolin disavows the claim that these are critiques. For him, these attributes and tendencies of democracy are advantageous and valuable. Their abrupt appearance in sharp and finite moments of fugitive democracy reveals that the memory and experience of democracy still can be found within the inhospitable confines of late modernity.

Examining frontier vigilantism confirms the truth of a democratic impulse toward formlessness. Although frontier vigilantes were not revolutionaries and had no intention of destroying existing political forms permanently, they shared in fundamentally revolutionary delights. They relished seeing their political world turned upside down, and they savored the anarchic freedom and equality implied by halting existing structures of government. But the phenomenon also suggests a countervailing need for forms and structure in the midst of a political space marked by shapeless indeterminacy. The overwhelmingly amorphous quality of the extra-legal realm impelled frontier vigilantes to establish forms that framed and patterned their actions. Without the benefit of a historical example, Wolin does not sufficiently appreciate the need for direction and systemization within the extra-legal realm.

Frontier vigilantes, of course, knew nothing of fugitive democracy or the terms of art that define it. Most frontier vigilantes were argonauts lured to California by the prospect of US\$20 a day diggings - a princely sum compared to the $\$ 1$ a day earned by most laborers - and, like most native-born white Americans who rushed toward gold, they were overwhelmingly male, relatively young and almost always hailed from back East (Paul and West, 2001, pp. 200-225). They came from all walks of life: laborers, farmers, merchants, doctors, lawyers, politicians, journalists, drifters, gamblers and ne'r-do-wells. But all were people of action who left their families behind and departed from the routine, structure and organization of their communities. What they found when they arrived was little gold, much competition and a multicultural milieu teeming with recent arrivals from China, Australia, France, Germany, Ireland and Italy, as well as with Mexicans, Native Americans and former slaves (Chan, 2000; Taylor, 2000; Paul and West, 2001, pp. 25-28, 253-283).

Although the historical scholarship on frontier vigilantism is voluminous and the phenomenon itself was quite varied, there are several agreed upon characteristics of the 210 known groups that appeared in the West (Brown, 1975, pp. 98-103, 110; Johnson, 1981, p. 560). Whether occurring in urban settings or in dusty, remote mining camps, these were collective acts of violence 
conducted by citizens acting of their own initiative. While public officials participated and frontier elite often took command of events, most vigilantes did not set out to change government and, for the most part, they left little institutional trace (Rosenbaum and Sederberg, 1976, pp. 3-29; Kirkpatrick, 2008, pp. 25-27, 39-61). Unlike revolutionaries that aim to depose the established government, vigilantes addressed a particular pragmatic goal, and they disbanded once this goal was attained, often in a matter of months or weeks. Some groups acted and dissolved in a matter of hours (Caughey, 1960; Brown, 1975, pp. 97, 103). Vigilantism was typically a violent affair, though the means and extent of the violence varied. In the early period, punishment could entail banishment, branding, flogging or hanging, whereas the later period is dominated by hanging. Most groups stopped after taking four or fewer lives (Brown, 1975, p. 109; Johnson, 1981, p. 569). Excluding three exceptional situations - the overland journey to the frontier, the very early days of the mining camps and the settlements in Alaska - frontier vigilantism took place in the presence of law enforcement, not its absence (Caughey, 1960, p. 8; Prassel, 1972, pp. 96, 129; Brown, 1975, pp. 123-124; Gordon, 1999, p. 256; Ridge, 1999, pp. 26-27; Pfeifer, 2004, pp. 28-33). Legal systems were stripped down and slight by today's standards, but they existed. The phenomenon also tended toward racism and xenophobia. In 90 per cent of cases in which ethnicity is revealed, the individual who initiated vigilante proceedings against the accused was white. In about half of the cases, the accused was non-white (Johnson, 1981, pp. 575-577). As Linda Gordon puts it, vigilantism 'has had a special affinity for the persecution of minorities, including ideological dissenters but particularly often racially subordinated groups' (Gordon, 1999, p. 258).

On the frontier, vigilantism typically appeared because of a sharp rise in crime, usually murder or theft, or because of public outcry over an unforgivable injustice. In addition to stringing up alleged criminals, vigilantes punished legal officials accused of malfeasance, rid towns of rowdies and toughs, intervened in domestic disputes, restored property to a disabled miner and even kidnapped orphans. Whatever the problem, vigilantes argued that it surpassed the capabilities of formally constituted authorities. References to written statutes, courts and the physical embodiments of formal law (sheriffs, judges, jailors and the like) are overwhelmingly disparaging; institutional law was corrupt, overly bureaucratic and distorted (Gordon, 1999, p. 256; Pfeifer, 2004, pp. 94-109). 'Where the people looked for justice, they found too often jokes and jeers. It was not uncommon to see a judge appear upon the bench in a state of intoxication, and make no scruple to attack with fist, cane, or revolver any who offended him' (Bancroft, 1887, 37, p. 332). Unstintingly scornful of due process, vigilantes characterized legal procedures and 'technicalities' as mechanisms that hid deception and dishonesty. As Wyoming vigilantes wryly put it in a bit doggerel pinned to the body of one of their victims, 'Process of 
law is a trifle slow, So this is the way we have to go, Murders and thieves beware! PEOPLES VERDICT' (Pfeifer, 2004, p. 108). A popular vigilante saying echoes this sentiment: 'More justice, less law' (Gordon, 1999, p. 258). Thus, although the historical context of frontier vigilantes was distinct in many ways from Wolin's, vigilantes were animated by similar political concerns: suspicion of established legal and political structures, anxiety about a loss of political accountability and confidence in the capacity of popular power to address the political problem.

Pulling back from the legally constituted forms and routines was justified, vigilantes argued, by the democratic right of the people to intervene in an emergency. The resolutions of one vigilante group urges, for instance, that we

are believers in the doctrine of popular sovereignty; that the people of this country are the real sovereigns, and that whenever the laws, made by whom they have delegated their authority, are found inadequate to their protection, it is the right of the people to take the protection of their property into their own hands. (Mott, 1859, p. 16)

The standard view argued that the community could 'take back' its powers in a time of crisis, though the repossessed power was quite specific. As one contemporary commentator surmised: 'the movement of the people assumed the least objectionable form of resistance to authority, that of simply taking into their own hands the execution of the law, but leaving undisturbed the officers themselves' (Johnson, 1981, pp. 565-566). Uninterested in general or deliberative powers, vigilantes reclaimed the executive power to punish.

If one takes care to draw back from the lightening speed of the phenomenon and, in turn, to decelerate analysis of it, it is possible to perceive a crucial transition that Wolin's theory overlooks: the change from negation to creation. At this point, frontier vigilantes had backed themselves out of formally constituted government. By leaning heavily on the failures of legal authorities, by employing the urgent language of crisis and by depriving government of the power to punish, they quitted themselves of the state. This negation also thrust them into the rather unfamiliar and amorphous space outside of constitutional structures and forms. They stepped outside of the known properties of the state, divorced themselves from its expertise and resources, and bid farewell to familiar political principles. So doing, they entered a political space marked by this break. They faced the question: What next? What kind of politics should they create for themselves? How should they constitute politics in the extra-legal realm? The question for them was not whether - they did want to create something new - but what.

Addressing this daunting question, vigilantes constituted the extra-legal realm with borrowed ideas and institutions, not with novel creations. Confronting a vast array of political possibilities and poised on the cusp of 
imaginative beginnings, they recycled and reconfigured what they found enjoyable or satisfactory about American politics, while leaving unappealing aspects behind. Their collective action was wish fulfillment, and it revealed that their political dreams were largely conventional and traditional. Their wishes were not, in other words, rooted in an ambitious, rich, and complex notion like 'evanescent homogeneity', but rather in existing power inequalities and dominant hierarchies. Drawn to a white, male-centered violent ethic, vigilantism constituted the extra-legal realm as a racist, masculine space in which popular free will was regenerated through violence (Slotkin, 1974).

From the perspective of Wolin's theory, it is particularly disturbing that vigilantes link racist homogeneity to a key concept in radical democratic theory: popular sovereignty. Vigilantes had a repossessed power, the executive power to punish, but they needed an actor to move it. And in filling this need, they did not turn to the individual or even to the group. They turned to the sovereign people, a unified and cohesive political being endowed with the power to inspire awe, astonishment and dread. Because, in American politics, popular sovereignty is a common term with multiple meanings, it is crucial to clarify what vigilantes meant by it. In this context, popular sovereignty meant one thing: the power to make laws according to the will of the sovereign people. Laws in a state of emergency, like frontier men, should be self-made. Popular sovereignty did not, therefore, refer to the power to make foreign treaties, to declare war, to levy taxes or to set monetary policy, none of which concerned frontier vigilantes in the least. They cared only for the law, and they were jealous of it, feeling a deep antipathy toward intermediaries and interlopers. When the will of the sovereign changed, so too did the law.

In order to issue laws according to its will, the popular sovereign needed one will, a single and homogeneous desire. Although they saw unity as essential, oneness did not come naturally or without effort. Thus, frontier vigilantes issued admonitions: 'Be of one mind, and carry your point. The might, majesty, and power of the people can overcome all impending evils; like the thunders of heaven it will shake to naught all corruptive influences and drive its authors into oblivion' (Bancroft, 1887, 36, p. 460). They invoked stirring images of vigilantes 'ris[ing] as one man, summoned by almighty conscience' (Bancroft, 1887, 36, p. 16). They delighted in aspirational ideals of difference being 'swallowed in the one almighty thought of moral regeneration' and of 'all lesser sympathies and antipathies [being] laid aside' (Bancroft, 1887, 37, p. 677). And, when these devices fail to work, they legislated against dissent. Article VII of the Constitution of the 1856 Committee of Vigilance reads:

That the action of this body shall be entirely and vigorously free from all consideration of, or participation in the merits or demerits, or opinion or acts, of any or all sects, political parties, or sectional divisions in the 
community; and every class of orderly citizens, of whatever sect, party, or nativity, may become members of this body. No discussion of political, sectional, or sectarian subjects shall be allowed in the rooms of the association. (Constitution and addrress [sic] of the Committee of Vigilance of San Francisco, 1856, p. 4)

Cohesion and a sense of internal consistency among the sovereign people were also maintained by a healthy disdain for those seen as unalike. As Josiah Royce observed in 1886, there was a 'hearty American contempt' on the frontier 'for things and institutions and people that were stubbornly foreign, and that would not conform themselves to American customs and wishes' (Royce, 1886, p. 277). As one early chronicler of San Francisco put it, the French and Germans 'are not the dominant spirits of the place - for these are of the true American type that ever cry go ahead!' The 'genuine Yankee ... is a giant when he begins to work, tearing and trampling over the impossibilities of other races, and binding them to his absolute, insolent will' (Soulé, 1855, pp. 464-465). Vigilantes had 'the courage to take up authority, and the courage to lay it down. A community of Englishmen never would have moved; a community of Frenchmen never would have ceased moving short of the gulf of destruction' (Bancroft, 1887, 37, p. 669).

This hostility to those seen as different was not only visible in what vigilantes said, of course, but also in what they did. They terrorized competing Chinese mining camps, they hanged American Indians and they strung up Mexicans, or so-called greasers. Their hostility to minorities is reinforced by numerous in white-on-white vigilante killings in which the accused is marked as fundamentally dissimilar or as violating a foundational social norm (Bancroft, 1887, 36, pp. 547-553; Dane and Dane, 1941, pp. 262-275). To borrow from Hannah Arendt, frontier vigilantes relied on a long-standing method of putting 'a multitude into the place of a single person'. They employed 'the unifying power of a common enemy' (Arendt, 1965, p. 77).

In addition to reconstructing a racist version of popular sovereignty in the extra-legal realm, some frontier vigilantes also refashioned a defining feature of American constitutionalism: trial by a jury of one's peers. Particularly prevalent before 1860, trials typically involved the convocation of participants, the assignment of duties (prosecution, defense, judge, jury, witnesses and so on), an examination according to the agreed dictates of the trial, the determination guilt or innocence, a confession and the allotment of punishment. These trials could be elaborate affairs conducted by those with training in the law - indeed in one Oregon vigilante trial two future State Supreme Court justices played prominent roles - or simple events in which miners, downing their tools for a few hours, gathered in the camp's common space to judge and to mete out punishment (Shinn, 1885, pp. 190-198; Bancroft, 1887, 36, pp. 627-628). 
Still other trials were show trials, empty gestures intended to lend some legitimacy to what was, in truth, nothing more than the exercise of brute force. The use of the jury trial suggests that it filled a need, giving the anarchic impulses of injustice, frustration and indignation a defined and structured channel along which to move. Through the trial, a tumultuous sense of inequity not only became public, but also became comprehensible both to frontier vigilantes and the world at large because it was housed in a form that was both structured and recognizable.

While unstinting in their condemnation of established law, vigilantes described the law that issued from popular courts in different terms altogether. Stripped clean of undue legal procedures and unnecessary administrative apparatuses, these tribunals were characterized as a purer and less mediated form of law. The San Francisco vigilantes, for instance, proclaimed that they were believers in the 'grand republican principle' that 'the will of good people should be the law of our land' (Smith, 1883, p. 60). Popular Tribunals echoes this point: 'Law is the voice of the people' and 'Law is the will of the community as a whole' (Bancroft, 1887, 36, p. 9). As one advocate put it in a speech to a vigilante crowd, 'You are the people ... and the power the law has comes from you. When you feel a responsibility too great to trust [legal officials] you may take that power into your own hands again' (Dane and Dane, 1941, p. 266). Echoing the sentiments of the revolutionary era, vigilantes believed that the people's commands were articulated with the most clarity 'out of doors', that is, when they stood outside of legal institutions (Morone, 1990; Wood, 1998; Kramer, 2004). For vigilantes, law ideally recorded popular will, nothing more.

Some frontier vigilantes went further, recreating not only the trial, but a weak version of the rule of law as well. These vigilantes were solicitous, toward rules of their own making, especially when those rules enabled or enhanced their democratic power (Holmes, 1988, pp. 195-240). When addressing selfmade edicts that structured their trials, they were more likely to exhibit the qualities associated with the rule of law: They recognized when an established rule conflicted with the will of the majority and were willing to consider subjugating will to the requirements of the rule. To be sure, their commitment to their own rules was not rigid or strict (Elster, 2000). Nor did they think that their rules represented 'Peter sober' while popular will was 'Peter drunk', as Stephen Holmes has put it (Holmes, 1988, p. 196).

Yet these weak-rule-of-law vigilantes were generally mindful of constituent rules that organized their power and gave it direction and momentum (Holmes, 1988, p. 227). When they selected judges, listened to arguments by the prosecution and defense, and collectively voted on the guilt or innocence of the accused, they both created constituent rules and observed them. Indeed, some vigilantes wrote constitutions that expressed their shared principles and 
outlined the rules that governed their organization, a paradigmatic act of constituent power. This is not to say that disagreement, debate or controversy ceased after these constituent rules were in place. But the rules themselves, their content and meaning, exerted some influence on these disagreements (Waldron, 1998).

Other frontier vigilantes dispensed with a trial altogether or were outright cavalier with constituent rules, either ignoring them when they conflicted with their will or observing them in a way that gutted them of meaning. Consider, for instance, a popular tribunal sitting in judgment of a Mexican man accused of stealing livestock. In this case, the jury reached its verdict of 'not guilty', but this determination was deemed unacceptable by the rest of the vigilantes. 'You'll have to do better than that', they cried, as they sequestered the jury again with the promise of release after they arrived at the correct verdict. The jury deliberated for an additional half-hour, emerging with the acceptable verdict of guilty. They were greeted with grim, self-defeating news: 'We hung [sic] him an hour ago' (King, 1997, pp. 308-313). As this parody of a trial suggests, the abandonment of even a weak form of the rule of law gave license to a kind of popular power that was capricious, unpredictable and willful. These vigilantes could, for instance, accuse additional individuals during the trial or, after much elbow bending and with a pickled good cheer, they could acquit altogether (Delano, 1854, pp. 100-127; Bancroft, 1887, 36, pp. 547-553). They agreed with Rousseau's observation that it was 'absurd for the will to tie itself down for the future' (Rousseau, 1978, 2, p. 1). As well as being changeable and unstable, this power was expansive. Note how the jury bowed under pressure, reversing its decision in light of disproval and negating all desire for discord in the short span of half an hour. Tocqueville's observation that popular power touches the body as well as the soul comes to mind. It can be "vested with a force that is moral as well as material, which shapes wills as much as actions and inhibits not only deeds but also the desire to do them' (Tocqueville, 2004, 1, p. 15).

\section{Democracy and Constitutionalism: An Uneasy Alliance}

With its violent struggles wetting the slaughter bench with blood, its musty banality of lives gone by, and its seemingly uncreative march forward, history is not the natural habitat for some political theorists. If, as one view has it, a political theorist's vocation is to imagine the excellence of politics and thereby excite desire for it, then history is at best a deterrent and at worst a selfdefeating encumbrance. The sheer blood, muck and tedium of history can weigh down fruitful flights of the metaphysical, reducing soaring insights to half-lame hops. On this view, it may make sense to strike out methodologically 
in the opposite direction, heeding the insights of Stephen in James Joyce's Ulysses: 'History ... is a nightmare from which I am trying to wake'. Other political theorists have spurned this advice to great effect. Using history to deepen theory by explaining the transformations of intellectual thought over time and fruitfully incorporating historical context and events into theoretical analysis, they have argued that theory and history are inextricably bound together. For historically attuned theorists, history may be a nightmare, but it is a useful nightmare, and there is no waking up.

Although the traditional history of political thought approach has yielded significant insights, there are other possibilities for developing what Nietzsche called a 'historical sensibility' and for fostering its attending 'virtue of modesty' (Nietzsche, 2000, pp. 16-17). A different approach, taken up here, is to use history to criticize and evaluate theory. Using this method, Wolin's theory of fugitive democracy functions like a complex, finely wrought hypothesis, whereas frontier vigilantism provides historical data used to assess and appraise the theory. Of course the theory and the history exceed the tidy categories of hypothesis and data. There is far more to both. The aim is to find an illuminating and appropriate case with which to evaluate a theory that emphasizes an ephemeral political action in which ordinary citizens collectively resist constitutional, statist structures. Frontier vigilantism was largely a fleeting phenomenon: citizens organized to address a particular problem and, once this goal was met, they dissolved. Vigilantes acted collectively; these were neither state-sponsored affairs nor the acts of rogue individuals. They resisted formally constituted authorities, taking back the executive power to punish. They were violent, but the theory does not explicitly rule violence out. Perhaps most important of all, the connections between the theory and the case are embedded in the theory itself: Wolin identifies frontier communities as an example of fugitive democracy.

Although Wolin's theory points to this history, it does not make sufficient use of it. Without examining vigilantism, it is difficult to adequately comprehend the perilous nature of an unmitigated rejection of constitutionalism in the midst of an evanescent collective political action. By their nature, these are formless, chaotic, unstable and potentially violent political events, and they tend to prompt powerful feelings of liberation and potentiality. They spring from an antipathy to constitutional forms and are instigated by an act of negation. When pushed further in this direction, the inchoate nature of their action can be amplified in menacing and forbidding ways.

On the frontier, the amplification of formlessness occurred when frontier vigilantes, longing for strength, vigor and awe, embraced a unifying, often racist conception of popular sovereignty. As they put it, they wanted to move as 'one man' - the masculinism is telling - that is, with a velocity and force that would incite reverential fear and wonder in the accused, representative officials 
and in vigilantes themselves. Crossing the precipice of the extra legal and unsure of their collective ability to act within it, they reached for a radical democratic concept that traded on an all-powerful, all-knowing kind of political supremacy. They reached for popular sovereignty, a concept historically rooted not in the many but the one - that is, in the single, awe-inspiring office of the sovereign king. Intensifying the amorphous quality of the extra-legal realm, popular sovereignty was a force of fluidity, allowing the feckless and easily distracted will of the people to reign supreme. Moreover, the language of popular sovereignty encouraged eliminating what is distinct about a collectivist state of exception: it is instigated by a 'they' that is multiple, miscellaneous and multifarious. Among frontier vigilantes, popular sovereignty tended to instantiate a fascination with purity and completeness that was driven to root out difference and eliminate dissent. It eased the way toward a deep suspicion of dissimilitude and enmity to the unalike.

History reveals that this plunge in to a state of excessive inconstancy and impermanence is avoidable; the forces of formlessness can be productively checked through constitutionalism. Some frontier vigilantes sought a countervailing influence of structure, management, hierarchy and tradition by adapting the jury trial to their needs (Arendt, 1965, pp. 179-184; Frank, 2007). They rectified being thoroughly unbounded from political tradition by binding themselves to a particular aspect of that tradition. They constructed a legal 'outside' by bringing part of the legal 'inside' into it. Their example suggests the vital need of maintaining a productive tension between constitutionalism and democracy (McWilliams, 2007, pp. 3, 47). The historical case does not suggest that this reconstituted version of constitutionalism possessed the fortitude to defeat or overwhelm democracy, Wolin's constant concern. Rather, the modified and reconfigured version of constitutionalism laid the groundwork for a tense and edgy exchange between democracy and constitutionalism. It was through the jury trial that will and law met as mutually constituted and antagonistic forces. In addition, contra Wolin, constitutionalism, not democracy, was typically vanquished in this political context, defeated by the inchoate forces of the extra-legal realm and the feckless will of the popular sovereign. It is possible to imagine the work that the jury trial did being accomplished by other constitutional forms - like, for instance, the drafting of constitutional provisions or the election of popular representatives. The historical evidence does suggest caution about established political forms that are prone to being reconstituted as an unmediated conduit for popular will (the legislature, the president). In such situations, it is likely that constitutionalism will be effectively rendered mute.

History also underscores the allure and terror of the extra-legal realm. Stepping outside the constitutional opens up a blue sky of political possibility. Moving outside the realm of the legal, stuffed as it is with institutions, officials

280 (C) 2012 Macmillan Publishers Ltd. 1470-8914 Contemporary Political Theory Vol. 11, 3, 264-284 
and experts, and established political principles, entails moving into a political space of creation and possibility. Frontier vigilantes reveal the pleasure and fascination of this kind of political journey, of entering a space in which politics looks and feels distinct and thus invites novel political experiences and pleasures. But they also reveal the terror involved in crossing this boundary. Devoid as it was of established forms, the extra-legal realm prompted unprecedented questions and concerns. What does it mean to cease to be a part of the constitutional whole? What does political life outside of the categories and concepts that we have known all our lives look like? Although the political possibilities of the extra-legal realm might excite the organizational passions of a Lycergus, the vision and drive of a Moses or the even-handed prudence of a Lincoln, they proved daunting for ordinary citizens on the frontier.

History in the end reminds us of the tragic interplay between democracy and constitutionalism and reveals the political limits of the ordinary citizens who have been caught between them. Frontier vigilantes were human, utterly human. They compensated for trepidation with aggression, they masked their fragility with violence, and they recompensed their wildness with order and forms. The boundary of their political capacities was exposed fully in the extralegal realm, devoid as it was of experts, institutions or any other form of political cover. On some dimensions their denudation served them well, leading to an apprehensive accounting of the political dexterity necessary for stepping outside of the constitutional order and a humble assessment of their deficits in this regard. Confronted with the perils of the extra legal, they leaned on a constitutional crutch, the jury trial. In other dimensions, laying bare of their deficiencies led to reliance on a more pernicious aid, one that shut down the proliferation of difference and dissent and opened the way to reified hatreds. If, as Wolin hopes, ordinary citizens continue to venture into the alluring and terrifying space of the extra legal, it is necessary to account for the frailties and debilities of ordinary citizens when they find themselves on foreign terrain, outside of constitutionalism. We must account, more fully than a theory of fugitive democracy does, for their humanity.

\section{Note}

1 It is unclear from Wolin's description if evanescent homogeneity is accomplished in a Lockean state of nature by the kind of agreement that individuals make or by the substance of their agreement. The former would suggest that any act of endogenous collective agreement that accounts for the incomplete and partial nature of the community could produce evanescent homogeneity. The latter would demand that the agreement itself substantively acknowledges a common submission to law and affirms a common state of freedom and equality (that is, the Lockean obligation 'to observe the law of nature and to treat others as free and equal beings'). 


\section{References}

Arendt, H. (1965) On Revolution. New York: Viking Press.

Aristotle. (1984) The Politics, Translated by C. Lord. Chicago, IL: University of Chicago Press.

Ball, T. (2002) Review of Democracy and Vision: Sheldon Wolin and the Vicissitudes of the Political. Journal of Politics 64(3): 943-945.

Bancroft, H.H. (1887) The Works of Hubert Howe Bancroft, San Francisco, CA: History Company.

Beiner, R. (2004) Review of Democracy and Vision: Sheldon Wolin and the Vicissitudes of the Political. Bulletin of Science, Technology and Society 24(1): 60-62.

Brown, R.M. (1975) Strain of Violence: Historical Studies of American Violence and Vigilantism. New York: Oxford University Press.

Brown, W. (2007) Democracy and Bad Dreams. Theory and Event 10(1): 1-15.

Caughey, J.W. (1960) Their Majesties, the Mob. Chicago, IL: University of Chicago Press.

Chan, S. (2000) A people of exceptional character: Ethnic diversity, nativism, and racism in the California gold rush. In: K. Starr and R.J. Orsi (eds.), Rooted in Barbarous Soil: People, Culture, and Community in Gold Rush California. Berkeley, CA: University of California Press.

Connolly, W.E. (2001) Politics and vision. In: A. Botwinick and W.E. Connolly (eds.), Democracy and Vision: Sheldon Wolin and the Vicissitudes of the Political. Princeton, NJ: Princeton University Press.

Dane, G.E. and Dane, B.J. (1941) Ghost Town. New York: A.A. Knopf.

Delano, A. (1854) Life on the Plains and among the Diggings. Auburn, NY: Milner Orton \& Mulligan.

Elster, J. (2000) Ulysses Unbound: Studies in Rationality, Precommitment, and Constraints. New York: Cambridge University Press.

Frank, J. (2007) 'Unauthorized propositions': The federalist papers and constituent power. Diacritics 37(2-3): 103-120.

Gordon, L. (1999) The Great Arizona Orphan Abduction. Cambridge, MA: Harvard University Press.

Hart, H.L.A. (1961) The Concept of Law. Oxford: Clarendon Press.

Holmes, S. (1988) Precommitment and the paradox of democracy. In: J. Elster and R. Slagstad (eds.), Constitutionalism and Democracy. New York: Cambridge University Press.

Honig, B. (2001) Dead rights, live futures: A reply to Habermas's 'Constitutional Democracy'. Political Theory 29(6): 792.

Honig, B. (2007) The miracle of metaphor: Rethinking the state of exception with Rosenzweig and Schmitt. Diacritics 37(2-3): 78-102.

Honig, B. (2009) Emergency Politics: Paradox, Law, Democracy. Princeton, NJ: Princeton University Press.

Johnson, D.A. (1981) Vigilance and the law: The moral authority of popular justice in the far west. American Quarterly, Special Issue: American Culture and the American Frontier 33(5): $558-586$.

Kalyvas, A. (2008) Democracy and the Politics of the Extraordinary: Max Weber, Carl Schmitt, and Hannah Arendt. New York: Cambridge University Press.

Kateb, G. (2001) Wolin as a critic of democracy. In: A. Botwinick and W.E. Connolly (eds.), Democracy and Vision: Sheldon Wolin and the Vicissitudes of the Political. Princeton, NJ: Princeton University Press.

King, C. (1997) Mountaineering in the Sierra Nevada. In: F.P. Farquhar (ed.), Lincoln, NE: University of Nebraska Press.

Kirkpatrick, J. (2008) Uncivil Disobedience: Studies in Violence and Democratic Politics. Princeton, NJ: Princeton University Press.

Kramer, L. (2004) The People Themselves: Popular Constitutionalism and Judicial Review. Oxford: Oxford University Press.

282 (C) 2012 Macmillan Publishers Ltd. 1470-8914 Contemporary Political Theory Vol. 11, 3, 264-284 
McCormick, J.P. (1997 Carl Schmitt's Critique of Liberalism: Against Politics as Technology. New York: Cambridge University Press.

McWilliams, W.C. (2007) Power after power: Reflections on liberalism in Politics and Vision. Theory and Event 10(1): 1-27.

Morone, J.A. (1990) The Democratic Wish: Popular Participation and the Limits of American Government. New York: Basic Books.

Mott, M.H. (1859) History of the Regulators of Northern Indiana: Published by Order of the Central Committee. IN: Indianapolis Journal Company Printers.

Nietzsche, F.W. (2000) Human, All Too Human (1): A Book for Free Spirits, Translated by G. Handwerk. Palo Alto, CA: Stanford University Press.

Paul, R.W. and West, E. (2001) Mining Frontiers of the Far West, 1848-1880. Albuquerque, NM: University of New Mexico Press.

Pfeifer, M.J. (2004) Rough Justice: Lynching and American Society, 1874-1947. Urbana, IL: University of Illinois Press.

Prassel, F.R. (1972) The Western Peace Officer: A Legacy of Law and Order. Norman, OK: University of Oklahoma Press.

Ridge, M. (1999) Disorder, crime, and punishment in the California gold rush. Montana: The Magazine of Western History 49(3): 11-27.

Rosenbaum, H.J. and Sederberg, P.C. (1976) Vigilante Politics. PA: University of Pennsylvania Press.

Rousseau, J.-J. (1978) On the Social Contract with Geneva Manuscript and Political Economy. In: R.D. Masters (ed.), New York: St. Martin's.

Royce, J. (1886) California, from the Conquest in 1846 to the Second Vigilance Committee in San Francisco: A Study of American Character. New York: Houghton Mifflin.

San Francisco Committee of Vigilance. (1856). Constitution and addrress [sic] of the Committee of Vigilance of San Francisco. San Francisco, CA: Morning Globe.

Scheuerman, W.E. (1994) Between the Norm and the Exception: The Frankfurt School and the Rule of Law. Cambridge, MA: MIT Press.

Schmitt, C. (2005) Political Theology: Four Chapters on the Concept of Sovereignty. Chicago, IL: University of Chicago Press.

Shinn, C.H. (1885) Mining Camps: A Study in American Frontier Government. New York: C. Scribner's Sons.

Slotkin, R. (1974) Regeneration through Violence: The Mythology of the American Frontier, 1600-1860. Middletown, CT: Wesleyan University Press.

Smith, F.M. (ed.) (1883) San Francisco Vigilance Committee of '56, with Some Interesting Sketches of Events Succeeding 1846. San Francisco, CA: Barry Baird \& Co.

Soule, F. (1855) The Annals of San Francisco. New York: Appleton.

Taylor, Q. (2000) African-American men in the American West, 1528-1990. The Annals of the American Academy of Political and Social Science 569(102): 102-119.

Tocqueville, A.de (2004) Democracy in America, Translated by A. Goldhammer. New York: Library of America.

Waldron, J. (1998) Precommitment and disagreement. In: L. Alexander (ed.), Constitutionalism: Philosophical Foundations. Cambridge, MA: Cambridge University Press.

White, S.K. (2001) Three conceptions of the political: The real world of late modern democracy. In: A. Botwinick and W.E. Connolly (eds.), Democracy and Vision: Sheldon Wolin and the Vicissitudes of the Political. Princeton, NJ: Princeton University Press.

Wolin, S.S. (1993) Democracy, difference, and re-cognition. Political Theory 21(3): 464- 483.

Wolin, S.S. (1994) Norm and form: The constitutionalizing of democracy. In: J.P. Euben, J.R. Wallach and J. Ober (eds.), Athenian Political Thought and the Reconstruction of American Democracy. Ithaca, NY: Cornell University Press.

(C) 2012 Macmillan Publishers Ltd. 1470-8914 Contemporary Political Theory Vol. 11, 3, 264-284 283 
Wolin, S.S. (1996) Fugitive democracy. In: S. Benhabib (ed.), Democracy and Difference: Contesting the Boundaries of the Political. Princeton, NJ: Princeton University Press.

Wolin, S.S. (2004) Politics and Vision: Continuity and Innovation in Western Political Thought. Princeton, NJ: Princeton University Press.

Wolin, S.S. (2008) Democracy Incorporated: Managed Democracy and the Specter of Inverted Totalitarianism. Princeton, NJ: Princeton University Press.

Wood, G.S. (1998) The Creation of the American Republic, 1776-1787. Chapel Hill, NC: University of North Carolina Press.

Xenos, N. (2001) Momentary democracy. In: A. Botwinick and W.E. Connolly (eds.), Democracy and Vision: Sheldon Wolin and the Vicissitudes of the Political. Princeton, NJ: Princeton University Press. 